\title{
Quality of packaged drinking water marketed in Douala - Cameroon
}

\author{
Marlyne-Josephine Mananga ${ }^{1}$, Marie Modestine Kana Sop ${ }^{2}$, Etienne Nguidjol $^{3}$, Inocent Gouado ${ }^{2, *}$ \\ ${ }^{1}$ University of Yaoundé I, Faculty of Science, Department of Biochemistry, Yaoundé, Cameroon \\ ${ }^{2}$ University of Douala, Faculty of Science, Department of Biochemistry, Box 24157 Douala, Cameroon \\ ${ }^{3}$ Laboratory of physicochemical and microbiological analysis of water, HYDRAC Society, Box: 12806 Douala, Cameroon \\ E mail address: \\ gouadoi@yahoo.fr (I. Gouado)
}

\section{To cite this article:}

Marlyne-Josephine Mananga, Marie Modestine Kana Sop, Etienne Nguidjol, Inocent Gouado. Quality of Packaged Drinking Water Marketed in Douala - Cameroon. Journal of Water Resources and Ocean Science. Vol. 3, No. 6, 2014, pp. 74-79. doi: 10.11648/j.wros.20140306.12

\begin{abstract}
Quality and safety of water are very important for the health. The proliferation of conditioned drinking water in urban areas of Cameroon these years raises the problem of quality control. This research was then conducted in Douala town, to determine microbiological and physicochemical qualities of local and imported conditioned drinking water, in order to inform consumers and help them to make better choices. After the survey carried out with the population in Douala town, 32 drinking packaged water in polyethylene bags and bottles were collected and analyzed. The choice was made according to the amount of the persons using this water. The research of the total germs was done by the Plate Count Agar, the coliforms determined by the Eosin Methylen Blue and staphylococcus by the Chapman medium. The hardness, the concentration of calcium and magnesium were determined by complexometric method using tetra acetic diamine ethylen (EDTA). The pH, the turbidity and the conductivity were determined respectively by a $\mathrm{pH}$ meter, turbidimeter and a conductimeter. Chlorides and nitrates were measured by UV spectrometric method. According to the results obtained, consumers surveyed choose a type of brand water for economic reasons, $82 \%$ of trademarks investigated had worst sanitary safety. The analytical results demonstrated that $76 \%$ of water produced in Douala are soft $\left(0^{\circ} \mathrm{F}<\mathrm{TH}<15^{\circ} \mathrm{F}\right)$, weakly mineralized (total dissolved solid $<500 \mathrm{mg} / \mathrm{L})$ with $\left[\mathrm{Ca}^{2+}\right]<100 \mathrm{mg} / \mathrm{L}$ and $\left[\mathrm{Mg}^{2+}\right]<50 \mathrm{mg} / \mathrm{L}$. However, $100 \%$ of imported water analyzed were very hard $\left(\mathrm{TH}>43^{\circ} \mathrm{F}\right)$ and highly mineralized. Water packed in bags harbored numerous species of bacteria including Pseudomonas cepacia, Acinetobacteria, and nonpathogenic Staphylococcus; their densities were respectively, 23x10 $\pm 3605,55$ CFU.100 $\mathrm{mL}^{-1}, 22 \times 10^{3} \pm 1732,05$ to $54 \times 10^{3} \pm 4582,57 \mathrm{CFU} .100 \mathrm{~mL}^{-1}$ and $23 \times 10^{3} \pm 2000 \mathrm{CFU} .100 \mathrm{~mL}^{-1}$. Conditioned water produced in Douala (in bags) had the worse microbiological quality than the imported water. On the contrary they are softer than imported water.
\end{abstract}

Keywords: Drinking Water, Quality, Norms, Waterborne Diseases, Douala

\section{Introduction}

Water is second to oxygen as being essential for life. People can survive days, weeks, or even longer without food, but only about four days without water. Water makes up about $60 \%$ of the human body. Most of the living tissue of a human being is made up of water; it constitutes about $92 \%$ of blood plasma, about $80 \%$ of muscle tissue, about $60 \%$ of red blood cells and over half of most other tissues (Turgut et al., 2005).

It covers some $70 \%$ of the earth's surface, with only $3 \%$ being from fresh water sources. With the world population growing and the increasing pollution of our natural resources, we are facing a water crisis. The World Health Organization has estimated that over 1 billion people lack access to safe drinking water and about 4000 children die every day from water borne disease (Virkutyte and Sillanpa, 2006). The World Health Organization estimates that 500 million diarrhea cases reportedly taking place each year in children less than five years in Asia, Africa and Latin America (WHO, 1972-73). UNICEF estimated that about $60 \%$ of child deaths worldwide are attributed to infectious or parasitic diseases related to water, the most frequent are gastro enteritis. About 2.3 billion of people suffer from infectious gastro enteritis 
each year (UNICEF, 2001). The extent of enteric diseases in different areas depends upon the extent to which water is exposed to contamination. The incidence of typhoid fever, bacillary dysentery, infectious hepatitis and other enteric infections are common and are transmitted through contaminated water. Cholera is still a wide spread water borne disease in some developing countries. There are numerous other diseases that are transmitted through polluted water. (Afia et al., 2006; Delolme et al., 1992). According to WHO, drinking water should be clear, colorless, odorless, tasteless and free of pathogens or other toxic chemicals (OMS, 1994).

Douala, Cameroon's economic capital, although it has a distribution network of drinking water through a national company, has in recent years, an increase in production and consumption of drinking packaged water. These water are mainly composed of spring water, treated water and natural mineral water. Each type of water is subject to specials restrictions related to its operating system, its packaging or its composition (Touridomon et al., 2009). In the city of Douala, there are several brands of drinking packaged water in plastics bottles or in polyethylene bags, produced locally or imported.

Much work has already been conducted in several countries on the quality of drinking water in order to protect the consumers (Birley, 1991; Pathak et al. 1993; Boutin, 1993; Makoutode et al., 1999): Some tests have been done on the microbiological and, or physicochemical properties of drinking packaged water in Tunisia (Khosrof and Boudabous., 1992), in Ivory Coast (Blé et al., 2009), in Algeria (Djellouli et al., 2005) and in Burkina Faso (Touridomon et al., 2009). In Cameroon, studies were mainly focused on the quality of spring water, wells, rivers and the distribution network (Nola et al. 1998; Tatkeu 2001; Sena 2001). However, the review of the literature is lacking data necessary for water quality monitoring and information management.

This study was then conducted in the town of Douala in order to determine the microbiological quality and physicochemical composition of drinking water packaged in order to highlight potential risks of waterborne diseases that the populations could be exposed to.

\section{Methods and Materials}

\subsection{Sampling}

The Douala Town is located at latitude $4^{\circ}$ North and longitude $9^{\circ}$ East. The relief is made up of many sedimentary rocks. It is influenced by a classical equatorial climate and made up of ferralitic soils (Mamert, 2000).

From January to April 2009, a survey was conducted among 388 consumers, 20 districts and 89 outlets in the city of Douala. It aimed to identify drinking water brands consumed most and locate the various places of purchase. Thirty two (32) brands of packaged drinking water including 25 locally produced and imported, 07 were purchased in supermarkets, power supplies around schools, markets and shops in the city of Douala. For each brand, three (03) samples were collected.

\subsection{Methods}

\subsubsection{Microbiological Analysis}

The Plate Count Agar medium (Humeau laboratory, ref. 550150300-54) was used for the enumeration of total germs in the water. The Eosin Methylen Blue (Scharlau laboratory, ref. 01-592) for enterobacteria. The Mannitol Salt Agar (Chapman medium) (Scharlau, ref. 01-116) was used for the detection of staphylococci. The API 20E galleries (Bioméreux laboratory, ref. 20100- 20160) were used for the identification of Enterobacteria.

\subsubsection{Physicochemical Analysis}

Chloride and nitrate ions were assayed by the spectrophotometric method using a spectrophotometer (Unicam 500). The hardness, the concentration of calcium and magnesium ion were determined by complexometric method with ethylen diamine tetra acetic acid as disodium $\left(\mathrm{Na}_{2}\right.$ EDTA).The bicarbonate content was performed from the values obtained from the full title alkalimetric. The temperature, $\mathrm{pH}$, conductivity and turbidity were determined from an electronic temperature probe Testo 925, $\mathrm{pH}$-meter Denver, conductivity by the conductimeter Hanna and turbidity were done by turbidimeter Hanna. A conversion by a corresponding factor of the conductivity allowed to assayed total dissolved solids (TDS).

\subsubsection{Statistical Analysis}

The software used was Statgraphics Centurion. The analysis of average and standard deviations allowed us to compare the physicochemical composition of different packaged drinking water. The multiple comparison test of Duncan has allowed us to compare the different drinking water standards.

\section{Results and Discussion}

\subsection{Survey}

Water packed in polyethylene bags are water consumed by a large portion of the population for economic reasons. However, the main reasons for the choice of imported water remain for their quality and availability.

\subsection{Health Survey at Outlets}

This study was conducted in 20 districts of the city of Douala. $82 \%$ of outlets inspected had inadequate sanitary conditions. The bags of water were spread on the ground, sometimes placed in freezers in contact with meat, fish or other foods. $52.81 \%$ of the outlets had very congested soil allowing the free movement of cockroaches, villains, lizards and mice over pallets of water. Some of these creatures came even sometimes and leave their droppings on top of these pallets behind them. In other outlets packaged water were exposed to the weather such as they were placed under the 
sunshine or in direct contact with rainwater. This result leads to a deposit of a huge layer of dust over the packaging of drinking water. $13.48 \%$ of the outlets were located near the garbage. Only $17.98 \%$ of the shops showed hygiene compliance. The floors and walls maintained the commercial space being ventilated with air conditioners, surfaces covered with tile.

\subsection{Health Survey of Consumer}

Eighty-seven per cent $(87 \%)$ of consumers revealed to take no hygienic precautions before ingestion of drinking packaged water. After our investigation, we can say that despite the fact that waterborne diseases reported by people could come from the quality of water consumed, but also that failure to follow basic hygienic rules by traders and consumers would also provide a huge source of contamination and spread of waterborne diseases.

\subsection{Microbiological Analysis}

In Cameroon, the drinking water standards apply to packaged drinking water are the guidelines values of WHO. Packaged water analyzed show that the water of local production do not meet the standards. Their total count rate is higher than two thousand (2000) total germs in $100 \mathrm{~mL}$. According to WHO, water of good microbiological quality should contain less than two thousand (2000) total germs $/ 100 \mathrm{~mL}$.

According to table 1, $16 \%$ of drinking packaged water of locally production are polluted. This rate is higher than that obtained by Feumba et al., (2009) on the water consumed in the district of Bonangang (13.33\%) and Tatkeu (2001) on Water of network distribution of Cameroon $(0 \%)$. This difference is due particularly to the influence of processing methods on the microbiological quality of water consumed and on the other hand, the state's distribution network at the time of sampling. However, some authors such as Blé et al., (2009) notice that most of these packaged water collected in polyethylene bag on the market in Abidjan have concentrations of coliforms outsized respectively values of $78 / 100 \mathrm{~mL}$ and $32 / 100 \mathrm{~mL}$. Similarly, according to Khosrof et Boudabous (1992) mineral water of Tunisian show a pollution levels by $32 \%, 9.2 \%, 5.5 \%$ and $12 \%$ respectively due to the total germs, thermo tolerant coli forms, fecal streptococci and mold.

The results obtained in our study are consistent with those of Salim and Malik., (2008); Nola et al. (2000) and Sena (2001), who worked respectively on the bacteriological and physicochemical parameters of the mouth of the Oued Beni Messous, wells and spring water of Yaoundé and the bacteriological quality of water from springs and rivers of Dschang, Baleveng and Bafou (Cameroon). Considering these results and pollution levels observed in our study, we can say that the packaged water sold in the city of Douala are more suitable for consumption compared to Tunisian mineral waters, the waters of the Great Abidjan, marine waters, or still water wells and rivers of the Department of Menoua
(West Cameroon). It is noteworthy that $87.5 \%$ of samples tested were consistent over the WHO guideline value. The results reveal (table 2) few cases of non-compliance with the standards guidelines value of WHO (WHO, 1972-73). These water at concentrations higher or lower a number of germs that are indicators of pollution: Pseudomonas cepacia $\left(23 \times 10^{3} \pm 3605.55 \mathrm{CFU} / 100 \mathrm{~mL}\right)$, Acinetobacter spp $\left(22 \times 10^{3}\right.$ to $54 \times 10^{3} \pm 1732.05 \pm 4582.57 \mathrm{CFU} / 100 \mathrm{~mL}$ ) and non pathogenic staphylococci $\left(23 \times 10^{3} \pm 2000 \mathrm{CFU} / 100 \mathrm{~mL}\right)$. We observed that concentrations are substantially above those required by the WHO guidelines. All organisms identified are opportunists' pathogens germs. These germs do not have direct effects on health, but under certain conditions (temperature fluctuation). They can cause many health problems such as secondary infection or acute gastroenteritis (Maul et al., 1989). Several factors could explain the contamination of either count:

We have contamination of groundwater; the water is generally more vulnerable than its peak close to the soil surface (Guiraud and Galzy., 1984). The origin of bacteria in various types of groundwater is still debated, but those would come from mid-surface transport during the infiltration of surface water to groundwater (Nola et al., 2001).

Another factor of contamination could be a deterioration of facilities or the presence of cracks in the pipes that could cause infiltration of polluted water thereby polluting the catchment (Maul et al., 1989). The absence or inadequate treatment, inadequate investment and risk knowledge, poor maintenance of the production units of bottled water are all blocking factors and risk factors for groundwater pollution.

Exposure of polyethylene bags of water to solar radiation during the sale, contributes to bacterial growth because intense heat transforms the inactive chloride ions (Blé et al. 2009).

\subsection{Physicochemical Analysis}

The results are compiled in Tables 3, 4 and 5. It appears from these results that the majority of water brands analyzed had the $\mathrm{pH}$ between 6.5 and 8.5 which are values accepted by the WHO standards. The $\mathrm{pH}$ was $7.18 \pm 0.56$ (Table 5) for imported water, $6.56 \pm 0.86$ for the local production of water packaged in bags and $7.43 \pm 0,50$ for packaged water bottles. These changes in $\mathrm{pH}$ from one sample to another are due to the $\mathrm{CO}_{2}$ content of the water. For example, we noted a $\mathrm{pH}$ of 6 at Badoit bottled water which was carbonated water. Indeed according to Touridomon al., (2009), a high concentration of carbon dioxide $\left(\mathrm{CO}_{2}\right)$ would contribute positively to lower the $\mathrm{pH}$. The season climate, the geological land traversed and different treatments applied to safe drinking water influence the physicochemical composition of drinking water. The imported water are extremely hard, while the water of locally production are sweet (water packaged in bags) and moderately hard (water packaged in bottles). This is the case of trademarks Tanguy, Semme, Supermont, Natura, and Volcanic, Hesco water (Table 3). The analyzed imported water would be excellent for pregnant and lactating women, infants, the old persons (Benani-Nodot and Hardy, 2000). In 
the same idea, the results of the analysis of cations (calcium and magnesium) also show that these imported brands were rich in calcium $\left(\left[\mathrm{Ca}^{2+}\right]>150 \mathrm{mg} / \mathrm{L}\right)$ magnesium $\left(\left[\mathrm{Mg}^{2+}\right]\right.$ $<50 \mathrm{mg} / \mathrm{L}$ ) while the water of local production is low in calcium and magnesium. The low hardness of these local water is due to the chemical composition of the ground traversed.

Test results show that the anions of water imported brands were rich in bicarbonate $\left(\mathrm{HCO}_{3}{ }^{-}\right)$, especially the brand that has a Badoit content of $1076.04 \mathrm{mg} / \mathrm{L}$. The levels vary from bicarbonates $391.97 \pm 306.50$ for imported water, $15.20 \pm$ 11.23 for water bags and $155.88 \pm 47,35$ for bottled water produced locally. The test results showed that $\mathrm{NO}_{3}{ }^{-}$nitrate content varies from one brand of water to another. However, all observed values of nitrate meet the standards of WHO. We are seeing very high values in samples of produced water with local water brand Wally has a nitrate content of 24.56 and 17.03 for the brand Sweet Water (Table 3). This could be explained by the fact that these water brands have their point of capture in areas close to industrial discharges. The nitrate content of water varies according to season (Makoutode et al., 1999). It has been demonstrated that if a pregnant women consumes regular water rich in nitrates, it could increase the risk of methemoglobinemy in newborn baby (Rodier and al., 1996). Compared to the water of local production, the overal mineral content determined from the conductivity shows that all imported water were highly mineralized. The mean levels ranging from $0.72 \pm 0.62$ for imported water $0.09 \pm 0.09$ for water bags and $0,21 \pm 0.07$ for bottled water. The turbidity is
0 for imported water, $0.15 \pm 0.15$ for water bags. However, Table 5 shows that there is no significant difference between the imported water and water bottle wrapped in local production. The material used for packaging water locally produced bagged could be responsible for turbidity observed at these packaged water. Indeed for packaged water in bags at high temperatures or in poor storage conditions. The bags could release microparticles, which escape direct packaging and come into contact with drinking water and promoting the development of its turbidity (Blé et al., 2009).

\section{Conclusion}

This study allowed us to determine the physicochemical and microbiological quality of packaged drinking water sold in the city of Douala. It appears from this study that the people surveyed choose a type of brand water for economic reasons. Retail outlets and consumers had inadequate sanitary conditions. The microbiological parameter deserves strong vigilance because it represents an immediate risk to the health of consumers. It is therefore necessary to warn people of health risks. The physicochemical parameters reveals that locally produced water are soft, low mineral content: calcium and magnesium. However, the imported water was extremely hard, and highly mineralized in calcium and magnesium. More detailed studies of these packaged drinking water will have an exact idea of the quality of packaged water sold in the city of Douala.

Table 1. Rates of water pollution according to WHO standards

\begin{tabular}{lll}
\hline Origin of water samples & Imported & Local production \\
\hline Quantity of polluted brands & 0 & 4 \\
Quantity of analyzed brands & 7 & 25 \\
Pollution rate according to WHO & $0 \%$ & $16 \%$ \\
\hline
\end{tabular}

Table 2. Mean density of total bacteria (expressed as UFC/mL of water) and identification

\begin{tabular}{lllll}
\hline Samples & Golden & Ndiba & Sky Water & Cool \\
\hline Mean \pm SD & $23.10^{3} \pm 3605,55$ & $54.10^{3} \pm 4582,57$ & $22.10^{3} \pm 1732,05$ & $23.10^{3} \pm 2000$ \\
Isolated species & Pseudomonas cepacia & Acinetobacter spp & Acinetobacter spp & No pathogenic Staphylococci \\
\hline
\end{tabular}

Table 3. Physicochemical parameters of drinking packaged water (local brands)

\begin{tabular}{|c|c|c|c|c|c|c|c|c|c|c|c|}
\hline $\begin{array}{l}\text { Parameters } \\
\text { Brands }\end{array}$ & $\begin{array}{l}\text { Tur }(\mathrm{mg} / \mathrm{L} \\
\left.\text { of } \mathrm{SiO}_{2}\right)\end{array}$ & $\mathbf{p H}$ & $\begin{array}{l}\text { HTT } \\
(\mathbf{F}) \\
\end{array}$ & $\begin{array}{l}\mathrm{Ca}^{2+} \\
(\mathrm{mg} / \mathrm{L})\end{array}$ & $\begin{array}{l}\mathrm{Mg}^{2+} \\
(\mathrm{mg} / \mathrm{L})\end{array}$ & $\begin{array}{l}\mathrm{HCO}_{3}^{-} \\
(\mathrm{mg} / \mathrm{L}) \\
\end{array}$ & $\begin{array}{l}\text { Cl- } \\
(\mathrm{mg} / \mathrm{L})\end{array}$ & $\begin{array}{l}\mathrm{NO}_{3}^{-} \\
(\mathrm{mg} / \mathrm{L}) \\
\end{array}$ & $\begin{array}{l}\mathrm{NO}_{2} \\
(\mathrm{mg} / \mathrm{L}) \\
\end{array}$ & $\begin{array}{l}\text { Cond } \\
(\mu \mathrm{s} / \mathrm{cm})\end{array}$ & $\begin{array}{l}\text { TDS } \\
(\mathrm{g} / \mathrm{L})\end{array}$ \\
\hline Aquaba & 0.00 & 6.89 & 0.4 & 1.6 & 0.96 & 12.2 & 2.87 & 4.66 & 0.08 & 224 & 0.15 \\
\hline Aquavita & 0 & 6.11 & 0.35 & 1.4 & 0.13 & 17.08 & 0.51 & 0.81 & 0.03 & 57 & 0.04 \\
\hline Audes & 0.40 & 7.00 & 5.40 & 21.6 & 12.96 & 24.4 & 5.21 & 2.39 & 0.12 & 368 & 0.247 \\
\hline Bethesda & 0.41 & 4.27 & 0.617 & 2.45 & 0.23 & 0 & 2.33 & 8.57 & 0.07 & 57 & 0.04 \\
\hline Cool & 0.08 & 6.80 & 0.9 & 3.6 & 2.16 & 7.32 & 0.15 & 2.25 & 0.00 & 140 & 0.09 \\
\hline Delices & 0.02 & 7.05 & 5.4 & 21.6 & 12.96 & 12.48 & 13.36 & 1.43 & 0 & 54 & 0.03 \\
\hline Gecca & 0.25 & 7.01 & 6.84 & 27.37 & 10.87 & 10.25 & 1.11 & 0.79 & 0.16 & 22 & 0.02 \\
\hline Glanneuse & 0.01 & 7.01 & 4.6 & 18.4 & 11.04 & 26.108 & 4.68 & 0 & 0.01 & 135 & 0.09 \\
\hline Golden & 0.17 & 7.02 & 0.5 & 2.00 & 0.59 & 1.61 & 0 & 0.87 & 0 & 20 & 0.01 \\
\hline Hesco Water & 0 & 7.5 & 22.5 & 90 & 54 & 119.56 & 3.19 & 1.64 & 0 & 254 & 0.17 \\
\hline Namiwa & 0 & 5.38 & 3.8 & 15.2 & 9.12 & 14.64 & 11.01 & 0.43 & 0 & 32 & 0.02 \\
\hline Natura & 0 & 8.00 & 5.5 & 22 & 13.2 & 145.66 & 3.33 & 7.36 & 0 & 269 & 0.18 \\
\hline Ndiba & 0.09 & 7.00 & 3.56 & 14.24 & 8.54 & 39.04 & 0.49 & 0.86 & 0 & 108 & 0.07 \\
\hline
\end{tabular}




\begin{tabular}{|c|c|c|c|c|c|c|c|c|c|c|c|}
\hline $\begin{array}{l}\text { Parameters } \\
\text { Brands }\end{array}$ & $\begin{array}{l}\text { Tur }(\mathrm{mg} / \mathrm{L} \\
\left.\text { of } \mathrm{SiO}_{2}\right)\end{array}$ & pH & $\begin{array}{l}\text { HTT } \\
(\mathbf{F})\end{array}$ & $\begin{array}{l}\mathrm{Ca}^{2+} \\
(\mathrm{mg} / \mathrm{L})\end{array}$ & $\begin{array}{l}\mathrm{Mg}^{2+} \\
(\mathrm{mg} / \mathrm{L}) \\
\end{array}$ & $\begin{array}{l}\mathrm{HCO}_{3}{ }^{-} \\
(\mathrm{mg} / \mathrm{L})\end{array}$ & $\begin{array}{l}\begin{array}{l}\mathrm{Cl}- \\
(\mathrm{mg} / \mathrm{L})\end{array} \\
\end{array}$ & $\begin{array}{l}\mathrm{NO}_{3}^{-} \\
(\mathrm{mg} / \mathrm{L})\end{array}$ & $\begin{array}{l}\mathrm{NO}_{2} \\
(\mathrm{mg} / \mathrm{L}) \\
\end{array}$ & $\begin{array}{l}\begin{array}{l}\text { Cond } \\
(\mu \mathrm{s} / \mathrm{cm})\end{array} \\
\end{array}$ & $\begin{array}{l}\text { TDS } \\
(\mathrm{g} / \mathrm{L}) \\
\end{array}$ \\
\hline Semme & 0 & 8.6 & 14.8 & 59.4 & 35.61 & 246.44 & 18.61 & 2.90 & 0.05 & 517 & 0.346 \\
\hline Sky Water & 0.13 & 6.8 & 0.5 & 2.00 & 0.59 & 36.6 & 10.90 & 3.08 & 0 & 98 & 0.07 \\
\hline Source d'Orly & 0.36 & 4.63 & 4.35 & 17.4 & 10.44 & 4.88 & 6.99 & 3.09 & 0.04 & 511 & 0.34 \\
\hline Source de vie & 0.39 & 7.53 & 3.6 & 14.4 & 8.64 & 2.44 & 0.25 & 1.87 & 0.01 & 75 & 0.05 \\
\hline $\begin{array}{l}\text { Source du } \\
\text { Sahel }\end{array}$ & 0 & 7.03 & 4.7 & 18.8 & 11.28 & 43.42 & 7.35 & 1.81 & 0.04 & 73 & 0.05 \\
\hline Supermont & 0 & 7.00 & 21.8 & 87.2 & 52.32 & 122 & 3.50 & 7.73 & 0 & 228 & 0.153 \\
\hline Sweet Water & 0.24 & 6.7 & 2 & 8.00 & 4.8 & 12.93 & 6.06 & 17.02 & 0.00 & 344 & 0.23 \\
\hline Tangui & 0 & 7.00 & 9 & 36 & 21.6 & 136.92 & 2.62 & 0.11 & 0 & 304 & 0.204 \\
\hline Tati Water & 0.09 & 7.00 & 2.7 & 10.8 & 6.48 & 6.48 & 25.13 & 5.30 & 0.37 & 0.03 & 0.06 \\
\hline Volcanic & 0.08 & 7.03 & 9 & 36 & 21.6 & 164.7 & 2.11 & 0.98 & 0.21 & 330 & 0.22 \\
\hline Wally & 0.11 & 6.5 & 2.80 & 11.2 & 6.72 & 10.49 & 62.32 & 24.56 & 0 & 211 & 0.14 \\
\hline
\end{tabular}

TDS: Total Dissolved Solids; Tur: Turbidity; Cond: Conductivity; HTT: Hydro Titrimetric Title

Table 4. Physicochemical parameters of drinking packaged water (imported brands)

\begin{tabular}{|c|c|c|c|c|c|c|c|c|c|c|c|}
\hline $\begin{array}{l}\text { Parameters } \\
\text { Brands } \\
\end{array}$ & $\begin{array}{l}\text { Tur }(\mathrm{mg} / \mathrm{L} \\
\left.\text { of } \mathrm{SiO}_{2}\right)\end{array}$ & pH & $\begin{array}{l}\text { HTT } \\
\text { (F) }\end{array}$ & $\begin{array}{l}\mathrm{Ca}^{2+} \\
(\mathrm{mg} / \mathrm{L})\end{array}$ & $\begin{array}{l}\mathrm{Mg}^{2+} \\
(\mathrm{mg} / \mathrm{L})\end{array}$ & $\begin{array}{l}\mathrm{HCO}_{3}^{-} \\
(\mathrm{mg} / \mathrm{L})\end{array}$ & $\begin{array}{l}\mathrm{Cl}- \\
(\mathrm{mg} / \mathrm{L})\end{array}$ & $\begin{array}{l}\mathrm{NO}_{3}^{-} \\
(\mathrm{mg} / \mathrm{L})\end{array}$ & $\begin{array}{l}\mathrm{NO}_{2} \\
(\mathrm{mg} / \mathrm{L})\end{array}$ & $\begin{array}{l}\begin{array}{l}\text { Cond }(\mu \mathrm{s} \\
/ \mathrm{cm})\end{array} \\
\end{array}$ & $\begin{array}{l}\text { TDS } \\
(\mathrm{g} / \mathrm{L}) \\
\end{array}$ \\
\hline Badoit & 0 & 6 & 68 & 272 & 163.2 & 1076.04 & 19.77 & 4.10 & 0.02 & 1828 & 1.22 \\
\hline Beaupré & 0.17 & 7.6 & 43.3 & 173.2 & 103.92 & 250.1 & 8.03 & 0 & 0 & 410 & 0.27 \\
\hline Contrex & 0 & 7.6 & 110.3 & 441.2 & 264.72 & 322.08 & 10.29 & 1.77 & 0 & 2357 & 1.7 \\
\hline Evian & 0 & 74 & 20 & 80 & 48 & 28548 & 868 & 300 & 0 & 527 & 0.35 \\
\hline Hépar & 0 & 7.2 & 88.9 & 355.6 & 213.36 & 319.64 & 18.02 & 3.88 & 0.01 & 1668 & 1.12 \\
\hline Mont Blanc & 0 & 7.5 & 99 & 39.6 & 23.76 & 319.64 & 2.30 & 0 & 0.01 & 212 & 0.14 \\
\hline Roxanne & 0 & 7.00 & 15.4 & 61.6 & 36.96 & 170.8 & 11.3 & 1.94 & 0.08 & 359 & 0.24 \\
\hline
\end{tabular}

Table 5. Duncan test of multiple comparisons of different physicochemical parameters according to each type of drinking packaged water.

\begin{tabular}{|c|c|c|c|}
\hline \multirow{3}{*}{ Parameters } & \multirow{2}{*}{ Imported water } & \multicolumn{2}{|l|}{ locals water } \\
\hline & & bags & bottles \\
\hline & average & average & average \\
\hline Turbidity $\left(\mathrm{mg} / \mathrm{L}\right.$ of $\left.\mathrm{SiO}_{2}\right)$ & $0 \pm 0^{\mathrm{a}}$ & $0.15 \pm 0.15^{b}$ & $0.012 \pm 0.01^{\mathrm{a}}$ \\
\hline $\mathrm{pH}$ & $7.18 \pm 0.56^{\mathrm{ab}}$ & $6.57 \pm 0.87^{\mathrm{a}}$ & $7.43 \pm 0.50^{\mathrm{b}}$ \\
\hline HTT (F) & $50.83 \pm 39.20^{\mathrm{a}}$ & $2.82 \pm 2.08^{\mathrm{b}}$ & $13.77 \pm 7.15^{\mathrm{c}}$ \\
\hline $\mathrm{Ca}^{2+}(\mathrm{mg} / \mathrm{L})$ & $203.31 \pm 156.79^{\mathrm{a}}$ & $11.27 \pm 8.33^{\mathrm{b}}$ & $55.1 \pm 28.61^{\mathrm{c}}$ \\
\hline $\mathrm{HCO}_{3}^{-}(\mathrm{mg} / \mathrm{L})$ & $391.97 \pm 306.50^{\mathrm{a}}$ & $15.20 \pm 11.23^{b}$ & $155.88 \pm 47,35^{\mathrm{c}}$ \\
\hline $\mathrm{Cl}^{-}(\mathrm{mg} / \mathrm{L})$ & $11.20 \pm 6.01^{\mathrm{a}}$ & $13.92 \pm 7.43^{\mathrm{a}}$ & $6.41 \pm 5.56^{\mathrm{b}}$ \\
\hline $\mathrm{NO}_{3}^{-}(\mathrm{mg} / \mathrm{L})$ & $2.10 \pm 1.68^{\mathrm{a}}$ & $6.37 \pm 3.97^{b}$ & $3.45 \pm 3.30^{c}$ \\
\hline $\mathrm{NO}_{2}(\mathrm{mg} / \mathrm{L})$ & $0.03 \pm 0.02^{\mathrm{a}}$ & $0.05 \pm 0.03^{\mathrm{b}}$ & $0.08 \pm 0.04^{\mathrm{c}}$ \\
\hline Conductivity $(\mu \mathrm{s} / \mathrm{cm})$ & $1077.29 \pm 917.97^{\mathrm{a}}$ & $139 \pm 104.43^{\mathrm{b}}$ & $317 \pm 104.43^{c}$ \\
\hline Total dissolved solids (g/L) & $0.72 \pm 0.62^{\mathrm{a}}$ & $0.09 \pm 0.09^{\mathrm{b}}$ & $0.21 \pm 0.07^{\mathrm{c}}$ \\
\hline
\end{tabular}

The values which have in index exponent the different letters are significantly different $(\mathrm{p}<0.05)$ according to comparison multiple Duncan Test.

\section{Acknowledgements}

This study was realized with the partial support of Hydrocarbons-Analysis-Control society (HYDRAC).

\section{References}

[1] AFIA ZIA, HAMIDULLAH SHAH, SALEEMULLAH, MOHAMMAD NOMAN AND M. SHAFI SIDDIQI, (2006). Evaluation of heavy metals and pathogenic microorganisms in drinking water of Peshawar Valley. Asian Environ. Technol., 10: 08-09.
[2] AFNOR (Association Française de Normalisation) (1990). Eaux méthodes d'essais. $4^{\text {eme }}$ édition Paris 735.

[3] BENANI-NODOT A., HARDY J. (2000). Eau de boisson et santé. Les grandes sources de Wattwiller. Médecin, Jeunesse et Sports.

[4] BIRLEY M. (1991). Lignes et directives pour prévoir les implications pour les maladies transmises par des vecteurs du développement des ressources en eau. Sci.eau. 5 (1): 33-35

[5] BLE L., MAHAMAN B., BIEMI J., MIESSAN G., LEKADJOU S. (2009). Etude de la potabilité des eaux de boisson conditionnées en Côte d'Ivoire : Cas des eaux de la région du Grand Abidjan. European Journal of Scientific Research 28 (4) : 552-558 
[6] BOUTIN C. (1993). L'eau des nappes phréatiques superficielles, une richesse naturelle vitale mais vulnérable : l'exemple des zones rurales du Maroc. Sciences de l'eau, 6 : 357- 365 .

[7] DEGREMONT (1989). Mémento technique de l'eau tome1 et tome 2 .

[8] DELOLME, H., BOUTIN, J., ANDRE L-J, (1992). Eau douce et Pathologie. Médécine d'Afrique Noire: 39 (3).

[9] DJELLOULI HM., TALEB., HARRACHE-CHETTOUH D., DJAROUD S. (2005). Qualité physico-chimique des eaux de boisson du Sud-Algérien : Etude de l'excès en sels minéraux. Cahiers d'études et de recherches francophones / Santé. 15 (2) $: 1-7$

[10] FEUMBA R., KANA M., NGONO A., EBELLE R. (2009). Influence des méthodes de traitement sur la qualité microbiologique des eaux consommées au quartier BONAGANG (Douala-Cameroun). Sciences, Technologie et Développement 12 (1) 8-10.

[11] GIRAUD J. GALZY P. (1984). L'analyse microbiologique dans les industries alimentaires. Collection génie alimentaire, 92-119.

[12] KHOSROF S., BOUDABOUS A. (1992). Qualité microbiologique des principales eaux minérales tunisiennes. Microb.Hyg. Ali. 4 (11) : 4-16.

[13] MAKOUTODE M., ASSANI A., OUENDO E., AGUEH V., DIALLO P. (1999). Qualité et mode de gestion de l'eau de puits en milieu rural au Bénin : Cas de la sous- préfecture de Grand-Popo. Médecine d'Afrique Noire ; 46: 528-534.

[14] MAMERT, F.,(2000). Plan municipal de gestion de l'environnement de Douala, communauté urbaine de Douala

[15] MAUL A., VAGOST D., BLOCK J.C., (1989). Stratégies d'échantillonnage pour analyse microbiologique sur réseaux de distribution d'eau. Lavoisier Tec. Doc. (2-10) p.

[16] NOLA M., NJINE T., DJUIKOM E. FOKO S. (2000). Bacteria indicator dynamics in wells as influenced by well depth and well water column thickness, in Yaounde (Cameroon). AJST. 1 (2): 82-91.

[17] NOLA M., NJINE T., DJUIKOM E., FOKO S. (2001). Distribution des Pseudomonas aeruginosa et aeromonas hydrophila dans les eaux de la nappe phréatique superficielle en zone équatoriale au Cameroun et relations avec quelques paramètres chimiques du milieu. Rev. Sci. Eau. 14, 35-53.

[18] NOLA M., NJINE T., MONKIEDJE A., FOKO S. V., DJUIKOM E., TAILLEIEZ R. (1998). Qualité microbiologique des eaux de sources et des puits de Yaoundé. Cahier santé. 8 (5): 330-336.

[19] OMS (1994). Directives de qualité pour l'eau de boisson. $2^{\text {eme }}$ édition. OMS Genève 1-31.

[20] PATHAK S., BHATTACHERJEE J., RAY P., (1993). "Seasonal variation in survival and antibiotic resistance among various bacterial pollution in tropical rivers. J Gen. Appl. Microbiol. 39: 46-56.

[21] RODIER J., BAZIN C., BROUTIN J., CHAMBON P., CHAMPSAUR H., RODI L. (1996). L'analyse de l'eau, eaux naturelles, eaux résiduaires, eau de mer. 8 emédition Dunod Technique 915-1199.

[22] SALIM H., MALIK AIT K. (2008). Contribution à l'étude des paramètres physico-chimiques et bactériologiques de l'embouchure de l'Oued "Béni-Messous ». Mémoire en vue de l'obtention du diplôme des Etudes Universitaires Appliquées en sciences de la mer.

[23] SENA J. (2001). Evaluation de la qualité bactériologique des eaux de quelques sources et rivières des localités de Dschang, Bafou et Baleveng dans le Département de la Menoua. Mémoire de maîtrise de Biochimie. Université de Douala. 34p.

[24] TATKEU J. (2001). Evaluation de la qualité microbiologique de l'eau de consommation utilisée par une société de restauration de la ville de Douala: la Doual'air. Mémoire de maîtrise de Biochimie. Université de Douala. 30p.

[25] TOURIDOMON S. BANAO I., GOUADO I., TAPSOBA T . (2009). Composition physico-chimique des eaux de boisson conditionnées commercialisées à Ouagadougou (Burkina Faso). Cahier Santé 1:1-10.

[26] TURGUT, S., B. KAPTANOG, G. TURGUT, G. EMMUNGIL AND O. GENC, (2005). Effects of cadmium and zinc on plasma levels of growth hormone, insulin-like growth factor I and insulin-like growth factor-binding protein Biol. Trace Element Res., 108: 197-204.

[27] UNICEF (2001). Planning for health and socioeconomic benefits from water and environmental programs. Water environmental sanitation. 25: 32-41.

[28] VIRKUTYTE, J. AND M. SILLANPA, (2006). Chemical evaluation of potable water in Eastern Qinghai Province, China: Human health aspects. Finland. Environ. Int., 32: 8086.

[29] WHO, 1972-73. Guidelines for drinking water quality, Int. Health Criteria and Other Supporting Information.1st Edn., World Health Organization Geneva, 3: 101-146. 